\title{
Damian Talar
}

Uniwersytet Ekonomiczny we Wrocławiu e-mail: damiantalar2009@gmail.com

ORCID 0000-0002-5708-4159

WYKORZYSTANIE PODEJŚCIA ZASOBOWEGO

W BUDOWANIU WIZERUNKU

UCZELNI PUBLICZNEJ -
ANALIZA UNIWERSYTETU EKONOMICZNEGO
WE WROCLAWIU Z PERSPEKTYWY
KLUCZOWYCH ZASOBÓW ORAZ
ICH SPÓJNOŚCI ZE STRATEGIĄ I MISJĄ UCZELNI

THE USE OF RESOURCE BASED VIEW FOR IMAGE

CREATING OF A PUBLIC UNIVERSITY -

THE ANALYSIS OF THE WROCLAW UNIVERSITY

OF ECONOMICS AND BUSINESS

IN TERMS OF THE KEY RESOURCES

AND THEIR CONSISTENCE WITH THE UNIVERSITY'S STRATEGY AND MISSION

DOI: $10.15611 /$ pn.2019.11.20

JEL Classification: M000

Streszczenie: Celem artykułu była analiza posiadanych przez Uniwersytet Ekonomiczny we Wrocławiu zasobów, które mogłyby zostać wykorzystane do budowania wizerunku uczelni, a zarazem tworzyć jej trwałą przewagę konkurencyjną. Autor w swoich badaniach skupił się na stronie zarówno wewnętrznej, jak i zewnętrznej organizacji, by uniknąć zarzutów o jednostronność podejścia zasobowego, które uważa się za skoncentrowane wyłącznie na wnętrzu organizacji z pominięciem jej zewnętrznej strony. Przeprowadzone badania miały udowodnić, że odpowiednio przeprowadzona analiza, która została wsparta w niniejszym opracowaniu takimi narzędziami, jak mapa interesariuszy czy analiza VRIO (V - Value, R - Rare, I - Imitation, $\mathrm{O}$ - Organization), pozwala na wyodrębnienie zasobów, które można wykorzystać $\mathrm{w}$ procesie tworzenia wizerunku, a także budowania przewagi konkurencyjnej pod warunkiem zachowania ich spójności ze strategią i misją uczelni.

Słowa kluczowe: wizerunek, kluczowe zasoby, misja, strategia. 


\begin{abstract}
Summary: The purpose of the article was to analyze the resources held by the Wroclaw University of Economics and Business that could be used to build the image of the university and at the same time create its lasting competitive advantage. The author in his research focused on both the internal and external side of the organization to avoid allegations of one-sided resource approach, which is considered to be focused only on the inside of the organization bypassing its external side. The research was aimed at proving that properly conducted analysis, being supported in this study with such tools as a map of stakeholders or VRIO analysis (V-Value, R-Rare, I-Imitation, O-Organization), allows for the extraction of resources that can be used in the process of creating an image, as well as building a competitive advantage, providing that they are consistent with the university's strategy and mission.
\end{abstract}

Keywords: image, key resources, mission, strategy.

\title{
1. Wstęp
}

W czasach ogromnej popularności mediów społecznościowych oraz komunikacji elektronicznej zarówno organizacje, jak jednostki starają się tworzyć swój własny wizerunek. Działania te mają prowadzić do pozytywnej percepcji wśród odbiorców, a w przypadku organizacji - zarówno publicznych, jak i komercyjnych - do osiągnięcia celu ich działalności. Narzędziem, które do tego jest wykorzystywane, jest właśnie wizerunek.

Z pewnością istnieje wiele ujęć definicyjnych wizerunku i spora indywidualna percepcja tego określenia. W niniejszym artykule przyjęto, że wizerunek można traktować jako pewien wzór, odbicie lub obraz. Samo słowo wywodzi się z języka łacińskiego (imago) [Kotas 2014]. Dla pełniejszego kontekstu i zwiększenia spójności z poruszaną $\mathrm{w}$ tym artykule problematyką warto jeszcze odwołać się do słownika języka polskiego. Wizerunek jest tym samym co image, czyli wykreowanym przez daną osobę (lub na jej użytek przez innych) obrazem własnej osobowości. To również wypracowane (często przez specjalistów działających w tym zakresie) publiczne oblicze osoby lub organizacji, które przedstawia ją w korzystnym świetle i służy zdobyciu społecznej akceptacji dla jej działalności i równocześnie pozyskiwaniu coraz większej rzeszy sympatyków i klientów [Dunaj (red.) 1996, s. 317].

Nie da się z dnia na dzień zmienić percepcji otoczenia, jeśli do tej pory miało ono ściśle zdefiniowany kształt. Wszystko to jest rezultatem wybranych aktywności i realizowanej strategii $\mathrm{w}$ tym zakresie. Często konsumenci wybierają produkty określonych firm, społeczeństwo popiera stanowisko określonych osób czy też nawiązuje relacje z różnymi jednostkami właśnie na skutek konkretnego wizerunku, jaki do nich dociera i na którym skupia się indywidualna percepcja człowieka. Idąc tym tokiem rozumowania i rozpatrywania wizerunku, można traktować go w kategoriach zasobów, zwłaszcza gdy potraktujemy go jako coś, co organizacja lub człowiek wykorzystuje do osiągania swoich celów. Ta celowość stanowi fundamentalny punkt odniesienia przy odpowiednim wykorzystywaniu zasobów. 
Ciągłe osiąganie przewagi konkurencyjnej wymaga od organizacji stałego poszukiwania nowych źródeł tworzenia wartości. Patrząc na ewolucję zarządzania strategicznego, w którym można wyróżnić dominację pewnych podejść w konkretnych okresach, można stwierdzić, że aktualnie zdecydowanie większego znaczenia nabierają zasoby niematerialne, wśród których image zasługuje na szczególne miejsce. Można pokusić się o stwierdzenie, że zasoby materialne powinny być wykorzystywane w taki sposób, aby maksymalizować wartość wizerunkową, która przy odpowiednich działaniach i zachowaniu ich integralności z misją i strategią organizacji może stanowić determinantę sukcesu, także uczelni publicznej, która z punktu widzenia tego artykułu stanowi przedmiot badania.

\section{Znaczenie wizerunku dla uczelni publicznej}

Istnieje spora różnica między rolą wizerunku w organizacji komercyjnej i publicznej. Maksymalizacja wartości, która jest kluczowym aspektem działalności gospodarczej, idzie w parze z kreowaniem wizerunku w taki sposób, by zwiększyć sprzedaż produktu. W przypadku organizacji publicznej, jaką jest Uniwersytet Ekonomiczny we Wrocławiu oraz inne uczelnie publiczne, wizerunek odgrywa równie znaczną rolę. Tegu typu podmioty niosą ze sobą szerszą misję, której motywem przewodnim jest podnoszenie poziomu wykształcenia wśród społeczeństwa, czyli wartości, która sama w sobie może stanowić wizerunek. Gdyby przyjąć za poprawną analogię przedstawienia uczelni jako organizacji komercyjnej, studentów można potraktować jako klientów, którzy decydując się na wybór danego uniwersytetu, kupują produkt w postaci edukacji oraz dostępu do wszelkich zasobów uczelni.

Rola wykształcenia we współczesnym świecie jest istotna, a można ją rozpatrywać w kategoriach zarówno ekonomicznych, jak i demograficznych. Kształtuje ono głęboko zakorzenioną mentalność w odbieraniu nas przez innych członków społeczeństwa, ale wpływa również na sposób postrzegania samego siebie, co dodaje całości dodatkowo wymiar psychologiczny. Podążając tym sposobem myślenia, można założyć, że image uczelni jest główną determinantą przy wyborze studiów, a także przynależności społecznej jej absolwentów [Kotas 2014]. Znaczenie wizerunku uczelni dla jej wyboru przez studenta podkreślają tacy autorzy, jak Kotler i Fox, którzy wskazują go jako element wyróżniający uczelnię na tle innych szkół wyższych, a nawet jako kluczowy czynnik uzyskania przewagi konkurencyjnej. M. Krzyżak twierdzi, że tworzenie pozytywnego wizerunku i przychylnego stosunku do organizacji jest istotnym warunkiem realizowania misji społecznej przez szkołę wyższą [Krzyżak 2014]. Dejnaka zauważa z kolei, że „ppozytywny wizerunek zapewnia (...) relatywnie większą stabilność działania i mniejsze ryzyko" [Dejnaka 2012, s. 44].

Zarówno organizacje publiczne, jak i organizacje komercyjne popełniają często ten sam błąd w podejściu do wizerunku, uznając go za zasób, który można wytworzyć za pomocą działań promocyjnych w bardzo krótkim czasie. Wizerunek jest jed- 
nak czymś budowanym permanentnie i z założeniem, że cały proces podąża w określonym kierunku. Może to trwać przez lata, nim organizacja zacznie reprezentować zespół wartości i cech, który zdeterminuje sposób jej percepcji w otoczeniu.

Sam image można rozpatrywać w różnych kategoriach. Można wyróżnić jego kilka rodzajów. Istnieje image:

- rzeczywisty, który określa sposób, w jaki inni widzą organizację;

- lustrzany, który mówi o tym, jak pracownicy postrzegają organizację;

- pożądany, który mówi o tym, jak powinni widzieć jednostkę inni i jak pracownicy chcieliby widzieć swoją organizację;

- optymalny, który stanowi kompromis między wyżej wymienionymi wizerunkami i odpowiada na pytanie: jaki realny wizerunek można stworzyć w obecnej sytuacji [Rozwadowska 2002, s. 58].

Wizerunek pożądany i rzeczywisty niemal zawsze pozostają w pewnej odległości od siebie i niemożliwa jest ich pełna integracja. Wynika to z:

- niewłaściwego dopasowania atrybutów tożsamości do cech docelowego segmentu rynku;

- rozbieżności między deklarowanym a rzeczywistym zachowaniem jednostek;

- nieskutecznej komunikacji organizacji;

- oddziaływania konkurentów;

- zmienności otoczenia [Altkorn 2004, s. 18].

Pojęciem, które należy traktować jako składową wizerunku organizacji, jest jej tożsamość, którą najprościej można określić jako zestaw niepowtarzalnych cech, norm oraz wartości, pozwalający wyróżnić organizację z otoczenia i uczynić ją łatwą do rozpoznania (zidentyfikowania) za pomocą wzorców komunikacyjnych, jakie są w stanie wyrazić filozofię instytucji. Niektórzy autorzy wskazują dodatkowo na jej składową w postaci tożsamości wizualnej, pełniącej funkcję kodu, dzięki któremu organizacja przekazuje informacje (sygnały) umożliwiające budowanie jej pozytywnego wizerunku w otoczeniu [Krzyżak 2014].

Jak widać, nawet w przypadku organizacji, w których maksymalizacja wartości i wypłacanie dywidend głównym interesariuszom nie jest głównym celem działalności, znaczenie wizerunku jest znaczne. Umacnia to tylko w przekonaniu o słuszności traktowania go w kategoriach kluczowych zasobów niematerialnych, które determinują sukces organizacji. Kreowanie pozytywnego wizerunku szkoły wyższej powinno zapewnić taki stopień jego wyrazistości, aby umożliwiał on jednoznaczną percepcję uczelni. Pojawia się jednak problem z jego identyfikacją i mierzeniem, co oczywiście jest wynikiem jego niematerialnego charakteru, który trudno skalować [Iwankiewicz-Rak 2007]. Patrząc jednak z perspektywy przewagi konkurencyjnej, można stwierdzić, że wizerunek jest niemal niemożliwy do imitacji, co potwierdza jego wysokie znaczenie zasobowe. 


\section{Narzędzia budowania wizerunku uczelni publicznej}

Nieustannie zwiększająca się liczba narzędzi komunikacji, z jednej strony, ułatwia prowadzenie wszelkich działań związanych z kreowaniem wizerunku, z drugiej zaś - tworzy coraz większe wyzwania dla osób, które się tym zajmują. Istotną kwestią jest również dobranie odpowiednich środków do celu, jaki organizacja chce swoimi działaniami osiągnąć. Wreszcie dobór instrumentów powinien być dopasowany do grupy odbiorców oraz do zasobu, jaki będzie wykorzystywany w tym zakresie.

Warte odnotowania jest, że w przeciwieństwie do organizacji komercyjnych, które często dysponują bardzo wysokim budżetem, jaki mogą przeznaczyć na działania marketingowe, uczelnie publiczne te środki mają znacznie bardziej ograniczone. Zwykle więc muszą bazować na kreatywności i maksymalizowaniu tworzonej wartości przez alternatywne rozwiązania, nierzadko wspomagane przez samych studentów. Tym bardziej rośnie znaczenie i rola identyfikacji zasobów, które mogą stworzyć wartość wizerunkową. Ich potencjał często może równoważyć ograniczenia finansowe.

W literaturze odnajdziemy wiele narzędzi budowania lub kształtowania wizerunku. W przypadku działań zewnętrznych, którymi uczelnia publiczna może oddziaływać na otoczenie, można wyróżnić:

- komunikaty dla mediów (o wydarzeniach odbywających się na uczelni, np. jubileuszu istnienia uczelni),

- przekazy internetowe,

- artykuły (publikacje naukowe i popularnonaukowe pod szyldem uczelni),

- opisy przypadków biznesowych (opisy konkretnych programów, kampanii z życia uczelni, z którymi chce ona zaznajomić opinię publiczną),

- konferencje, seminaria, zjazdy,

- przemówienia (wygłaszane przez władze uczelni przy różnych uroczystościach),

- konferencje prasowe,

- wywiady,

- patronat medialny,

- mecenat,

- „dni otwarte” (uczelnie mogą odwiedzać osoby z zewnątrz),

- specjalną korespondencję (listy kierowane do interesariuszy z różnych okazji),

- wizualne kreowanie własnej tożsamości (ujednolicenie form kolorystyczno-graficznych, w tym nazwy i loga na stronach internetowych, wizytówkach itd.) [Pabian 2005, s. 239-242].

Patrząc na interesariuszy, których mapa została przedstawiona na rys. 1, można zauważyć, co nie jest zresztą żadnym zaskoczeniem, że najważniejszą grupę interesariuszy stanowią studenci. Bez wątpienia kluczową pozycję w portfelu narzędzi służących kreowaniu wizerunku będą odgrywać wtedy media społecznościowe. Oczywiście nie można ich wykluczać jako sposobu oddziaływania na inne grupy interesariuszy, choćby ze względu na rosnącą świadomość w tym aspekcie u starszych grup społeczeństwa. Za social mediami przemawiają jeszcze prostota i niski 
koszt prowadzenia różnego rodzaju działań mających na celu kreowanie wizerunku. Społeczność internetowa studentów, która jest budowana właśnie na portalach typu Facebook, jest w stanie najsilniej oddziaływać na postrzeganie uczelni nie tylko wśród samych studentów, ale również uczniów szkół średnich, którzy stoją u progu rozpoczęcia studiów.

\section{Zasoby relacyjne oraz ich znaczenie w kontekście wizerunkowym}

Opublikowany przez Hamela i Prahalada [1990] w 1990 roku artykuł The core competence of the corporation skłonił do postrzegania organizacji jako wiązki zasobów (resources) i umiejętności (capabilities), które do czasu jego publikacji były traktowane wyłącznie w kategoriach teoretycznych bez możliwości zastosowania takiego podejścia w praktyce, a co za tym idzie - do budowania przewagi konkurencyjnej organizacji.

Aby zasoby rozpatrywać w kategorii kluczowych dla organizacji i takich, które są w stanie zapewnić jej przewagę konkurencyjną, muszą przejawiać pewne cechy. David Collis i Cynthia Montgomery uważają, że kluczowy zasób powinien być:

- trudny do skopiowania,

- trwały (długo utrzymujący swoją wartość),

- kontrolowany przez firmę, a nie jej pracowników czy dostawców,

- trudny do zastąpienia innymi zasobami,

- lepszy od analogicznych zasobów posiadanych przez konkurentów [Collis, Montgomery 2008].

Według autorów tej koncepcji wręcz niemożliwe jest wskazanie organizacji wykorzystujących te same zasoby w identyczny sposób, natomiast samo wypracowanie zasobów wymaga precyzyjnej analizy otoczenia i dynamicznie zmieniającego się rynku.

W rzeczywistości trudno mówić o zasobach, które miałyby wszystkie wyżej wymienione cechy. Nie można też zakładać, że liczba zasobów, jakimi dysponuje organizacja, zagwarantuje jej sukces. Często można się spotkać z sytuacją, w której firmy charakteryzujące się teoretycznie ich wąską wiązką potrafią zaimplementować je do swojej strategii w taki sposób, że pozwalają osiągnąć przewagę konkurencyjną i generować wartość znacznie większą aniżeli firmy z dużo wyższym potencjałem zasobowym. Można w tego typu przypadkach mówić o niedopasowaniu zasobów firmy do jej aspiracji i strategii, jaką realizuje [Marczewska 2016].

Organizacja może skuteczniej wykorzystywać swoje zasoby na 5 podstawowych sposobów - przez ich: większe skoncentrowanie na celach strategicznych firmy (concentrating), lepsze ich gromadzenie ze źródeł zewnętrznych i wewnętrznych (accumulating), uzupełnienie jednego rodzaju zasobu innymi w celu podnoszenia ich wartości (complementing), ochronę zasobów (conserving) i odzyskiwanie zużywających się zasobów (recovering) [Hamel, Prahalad 1993]. 
Do jednych z najcenniejszych zasobów z perspektywy budowy wizerunku należą zasoby relacyjne. O słuszności tego stwierdzenia niech świadczy to, że zasoby te zawierają elementy każdej orientacji przedsiębiorstwa, w tym orientacje: prorynkowe, strategiczne, procesowe, na człowieka, na zmianę i wiedzę [Lichtarski 2014]. Dla podkreślenia znaczenia relacji należy wskazać, że są one postrzegane jako źródło przewagi konkurencyjnej [Dyer, Singh 1998], źródło renty relacyjnej [Stańczyk-Hugiet 2009], a nawet strategiczny zasób organizacji [Krupski 2012; Niemczyk 2013; Klimas 2014]. Oczywiście korzyść z takich relacji jest obopólna, ponieważ firmy, dla których pozytywny wizerunek wśród studentów jest istotnym elementem strategii rekrutacyjnej, również generują sporą wartość dodaną w tym zakresie. $\mathrm{W}$ odniesieniu do uczelni najważniejszą orientacją będzie przede wszystkim ta odnosząca się do wiedzy.

Tabela 1. Przykłady zasobów relacyjnych posiadanych przez Uniwersytet Ekonomiczny we Wrocławiu

\begin{tabular}{|l|l|}
\hline \multicolumn{1}{|c|}{ Podmiot } & \multicolumn{1}{c|}{ Przykład wykorzystania/tworzenia wartości przez UE } \\
\hline IBM & Studia podyplomowe, realizowane przez współpracę z firmą \\
\hline CCC & Studia podyplomowe, realizowane przez współpracę z firmą \\
\hline Lancerto & $\begin{array}{l}\text { Spotkanie zorganizowane przez Forum Edukacji Biznesowej z prezesem } \\
\text { i założycielem firmy }\end{array}$ \\
\hline Credit Suisse & $\begin{array}{l}\text { Oferta staży dla studentów Uniwersytetu Ekonomicznego we Wrocławiu, } \\
\text { angażowanie się firmy w wiele inicjatyw realizowanych przez uczelnię oraz } \\
\text { ich sponsorowanie }\end{array}$ \\
\hline BNY Mellon & $\begin{array}{l}\text { Oferta staży dla studentów Uniwersytetu Ekonomicznego we Wrocławiu, } \\
\text { sponsorowanie różnych wydarzeń, których organizatorem jest uczelnia }\end{array}$ \\
\hline $\begin{array}{l}\text { Janusz Filipiak } \\
\text { (COMMARCH) }\end{array}$ & Spotkanie organizowane z okazji 10-lecia Forum Edukacji Biznesowej \\
\hline
\end{tabular}

Źródło: opracowanie własne.

Należy zwrócić uwagę, że prezentowane w tab. 1 przykłady zasobów, jakimi posłużył się Uniwersytet Ekonomiczny we Wrocławiu, generują wartość dodaną dla organizacji właśnie w zakresie wizerunku, jak również bezpośredniej wartości dla studentów, którzy korzystają z nich w największym zakresie. Niepodważalne jest traktowanie ich wszystkich jako zasobów, które można wykorzystywać do kreowania wizerunku uczelni przede wszystkim ze względu na wysoką rozpoznawalność.

\section{Metodyka badań}

Zrealizowane badania empiryczne, których wyniki zostały zaprezentowane w następnym rozdziale, miały charakter wstępny i zostały zorientowane na identyfikację zasobów Uniwersytetu Ekonomicznego we Wrocławiu, które mogłyby zostać 
wykorzystane przy budowaniu wizerunku uczelni, przy jednoczesnym zachowaniu spójności ze strategią i misją uczelni realizowanymi w latach 2016-2020.

Punktem wyjścia do przeprowadzenia analizy Uniwersytetu Ekonomicznego we Wrocławiu było dogłębne zapoznanie się z misją i strategią uczelni, która została określona na lata 2016-2020. Stanowiło to najważniejszy krok do wybrania odpowiednich narzędzi i punktu odniesienia, jakie pozwoliłyby na wyodrębnienie tych zasobów, które mają szansę odnieść największy sukces w zakresie budowania wizerunku uczelni. W tym celu autor rozpoczął swoje badania o charakterze jakościowym od analizy interesariuszy organizacji, której wyniki zostały odzwierciedlone na mapie interesariuszy (rys. 1).

Pierwszym krokiem było zbudowanie mapy interesariuszy. Kolejnym - poszukiwanie działań, projektów, inicjatyw itp., prowadzonych przez uczelnię, które mają szansę najsilniej oddziaływać na najważniejsze grupy interesariuszy uczelni w zakresie wizerunkowym i jednocześnie realizować założoną strategię i misję uczelni, co miało również odpowiedzieć na pytanie stanowiące jeden z problemów badawczych tego opracowania odnośnie do spójności pomiędzy działaniami organizacji a określoną misją i strategią. W tym celu autor zbierał informacje wśród pracowników uczelni, a także szczegółowo analizował wszelkie dostępne źródła, w tym głównie właściwe strony internetowe, dostarczające informacji o aktywnościach, w jakie zaangażowany jest Uniwersytet Ekonomiczny we Wrocławiu. Badania te pozwoliły na wyselekcjonowanie działań, projektów, inicjatyw itp., które należy traktować w kategoriach kluczowych zasobów wizerunkowych uczelni.

Wreszcie badania skupiły się również na stronie zewnętrznej organizacji - w celu poznania czynników najsilniej oddziałujących na percepcję uczelni, a także dla próby zidentyfikowania zasobów wizerunkowych odbieranych przez stronę zewnętrzną organizacji. W tym celu analizie został poddany ranking uczelni ekonomicznych, stanowiący ważne narzędzie diagnostyczne dla całej uczelni pod kątem identyfikacji własnych zasobów wizerunkowych, a także jej słabszych stron w tym aspekcie, dostrzeganych przez otoczenie organizacji. Badania przeprowadzono w 2019 roku.

\section{Wyniki przeprowadzonych badań}

\subsection{Główni interesariusze Uniwersytetu Ekonomicznego we Wrocławiu}

Każda organizacja powinna znać swoich głównych interesariuszy i dobierać swoje działania w taki sposób, aby jak najsilniej na nich oddziaływały. Badanie, którego wyniki zostały odzwierciedlone na rys. 1, polegało na zidentyfikowaniu kluczowych dla uczelni interesariuszy, a następnie poddaniu ich ocenie według dwóch kategorii, takich jak siła nacisku i pilność żądań - w skali 1-10. Suma wyników uzyskanych w obu kategoriach odzwierciedla siłę oddziaływania poszczególnych interesariuszy na uczelnie, co zostało wyrażone za pomocą mapy interesariuszy Uniwersytetu Ekonomicznego we Wrocławiu. 


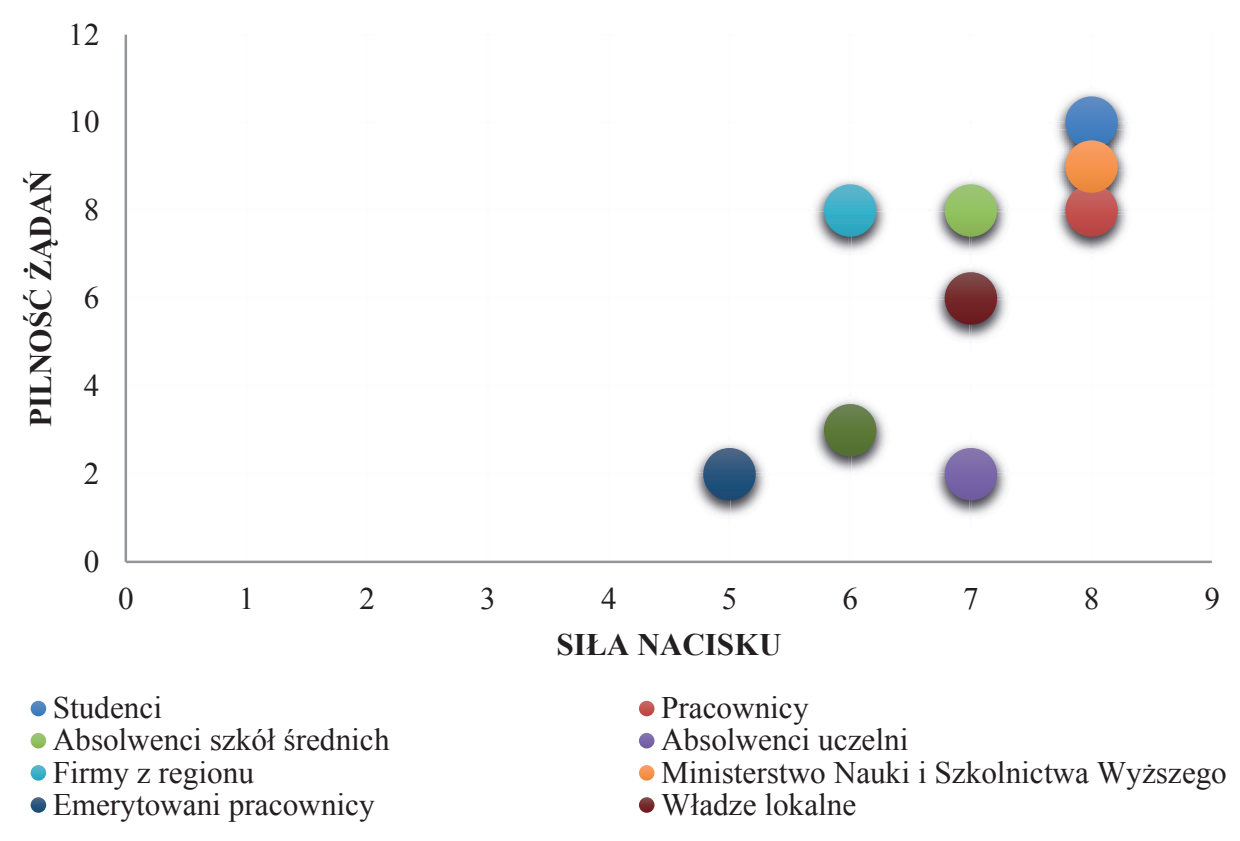

Rys. 1. Mapa interesariuszy Uniwersytetu Ekonomicznego we Wrocławiu według ich siły nacisku i pilności żądań

Źródło: opracowanie własne na podstawie własnych badań empirycznych.

W przypadku istnienia różnych grup interesariuszy należy zwrócić uwagę na konieczność dopasowania do nich odpowiednich kanałów komunikacji i zasobów, na jakich powinno się budować wizerunek. Waga, jaką konkretny interesariusz może przypisywać do określonego zasobu, często będzie się diametralnie różniła. Podobnie kanał komunikacji, zdominowany przez np. social media, będzie odgrywał najważniejszą rolę w przypadku docierania do studentów czy absolwentów szkół średnich, ale już znacznie mniejszą w odniesieniu do emerytowanych pracowników. Cała strategia budowania wizerunku musi więc uwzględniać wszystkich interesariuszy zarówno podczas procesu identyfikowania zasobów organizacji, jakie mogą zostać wykorzystane do tworzenia odpowiedniego wizerunku, jak i przy wyborze kluczowych działań, które będą przez uczelnie podejmowane w tym aspekcie.

\subsection{Kluczowe zasoby Uniwersytetu Ekonomicznego we Wroclawiu}

„Wizją Uniwersytetu Ekonomicznego we Wrocławiu jest uzyskanie statusu nowoczesnej jednostki edukacyjno-badawczej, opiniotwórczej i doradczej, trwale osadzonej w regionalnej, krajowej i międzynarodowej przestrzeni, podejmującej działania dla zrównoważonego rozwoju w poczuciu społecznej i etycznej odpowiedzialności, przyjaznej pracownikom, studentom i absolwentom oraz otwartej na całe swoje oto- 
czenie. Misją Uniwersytetu Ekonomicznego we Wrocławiu jest uzyskanie pozycji wiodącego ośrodka twórczej myśli i kształcenia ekonomicznego w naszym regionie Europy" (www.ue.wroc.pl).

Punktem wyjścia do budowania wizerunku jest zachowanie spójności z misją, wizją i wreszcie strategią organizacji. Nie można bowiem podążać inną ścieżką niż ta, która została zapisana i określona czasowo. Trzeba przy tym pamiętać, że działania organizacji powinny być nie tylko skoncentrowane na jej wnętrzu, co często stanowi zarzut wobec podejścia zasobowego, ale również uwzględnić wymagania i czynniki zewnętrzne. Umożliwia to wzajemne oddziaływanie na siebie działań skierowanych w stronę budowania wizerunku w taki sposób, aby ich wypadkowa odzwierciadlała konsensus wizerunkowy pomiędzy stroną wewnętrzną i zewnętrzną organizacji. Kluczem jest odpowiednie dopasowanie do siebie zasobów, jakich dostarcza nam analiza obu stron organizacji. W nawiązaniu do misji i wizji, które zostały przytoczone wyżej, oraz przez wykorzystanie odpowiednich narzędzi badawczych udało się zidentyfikować zasoby, jakie należy wykorzystać w odniesieniu do budowania wizerunku Uniwersytetu Ekonomicznego we Wrocławiu (tab. 2).

Tabela 2. Matryca kluczowych zasobów Uniwersytetu Ekonomicznego we Wrocławiu

\begin{tabular}{|l|l|l|l|}
\hline & \multicolumn{1}{|c|}{ Zasięg regionalny } & \multicolumn{1}{|c|}{ Zasięg krajowy } & \multicolumn{1}{|c|}{ Zasięg międzynarodowy } \\
\hline Nauka & Dolnośląski Festiwal Nauki & $\begin{array}{l}\text { Centrum Kształcenia } \\
\text { Ustawicznego (CKU) }\end{array}$ & Projekt SCALINGS \\
\hline Dydaktyka & $\begin{array}{l}\text { BIPS - Biznesowy } \\
\text { Indywidualny Program } \\
\text { Studiów }\end{array}$ & Studia MBA & $\begin{array}{l}\text { Program ERASMUS+ } \\
\text { 2014-2021 }\end{array}$ \\
\hline $\begin{array}{l}\text { Doradztwo/ } \\
\text { opiniotwórczość }\end{array}$ & $\begin{array}{l}\text { Uniwersytecki Inkubator } \\
\text { Przedsiębiorczości }\end{array}$ & $\begin{array}{l}\text { Członkostwo } \\
\text { w komitetach } \\
\text { naukowych PAN }\end{array}$ & $\begin{array}{l}\text { Międzynarodowa } \\
\text { Konferencja Młodych } \\
\text { Naukowców ACC } \\
\text { Euroregionu Nysa }\end{array}$ \\
\hline
\end{tabular}

Źródło: opracowanie własne na podstawie przeprowadzonych badań empirycznych.

Precyzyjne wybranie zasobów skłoniło autora do opracowania macierzy, tak aby w jak największym stopniu wykazane zasoby były dopasowane do misji, wizji i wreszcie strategii uczelni. W tym celu zostały ustalone trzy obszary, w jakich uniwersytet podejmuje swoje działania - nauka, dydaktyka oraz doradztwo i opiniotwórczość. Obszary te $\mathrm{z}$ kolei były rozpatrywane w trzech wymiarach zasięgu, tzn. regionalnym, krajowym i międzynarodowym. Warunkiem wyboru tych zasobów i działań było zidentyfikowanie związków z tym, co zapisane w wizji, misji oraz strategii Uniwersytetu Ekonomicznego we Wrocławiu. Dla pełnego obrazu zidentyfikowanych zasobów i zakwalifikowania ich w kategoriach wysokiej wartości dla organizacji została przeprowadzona dla każdego z nich analiza VRIO. Poniżej zamieszczono wyniki przeprowadzonej analizy, w której dla każdego z elementów: 
takich jak wartość, rzadkość, imitowalność oraz organizacja, skala oceny wynosiła 1-5. Poszczególne elementy należy interpretować w następujący sposób:

- Wartość określa, czy dany zasób umożliwia organizacji wykorzystywanie możliwości, jakie pojawiają się w otoczeniu i jednocześnie chroni ją przed zagrożeniami. W tym przypadku będzie to poprawienie wizerunku wśród interesariuszy.

- Rzadkość dotyczy zasobów, które mogą być wykorzystane wyłącznie przez daną organizację lub ewentualnie kilka organizacji.

- Imitowalność to przede wszystkim koszty, jakie inne organizacje musiałyby ponieść w przypadku chęci „skopiowania” zasobu, przy czym nie chodzi tutaj wyłącznie o koszty finansowe, ale również o te związane z wiedzą, dostępnością, poziomem organizacji, pomysłem itd.

- Organizacja określa poziom, na jakim przedsiębiorstwo - a w tym przypadku uczelnia - dostosowuje swoje systemy, procesy zarządzania, polityki czy kulturę. Tylko odpowiednio wysoki poziom organizacji pozwala jej na prawidłowe wykorzystywanie zasobów.

\section{Wartość poszczególnych zasobów}

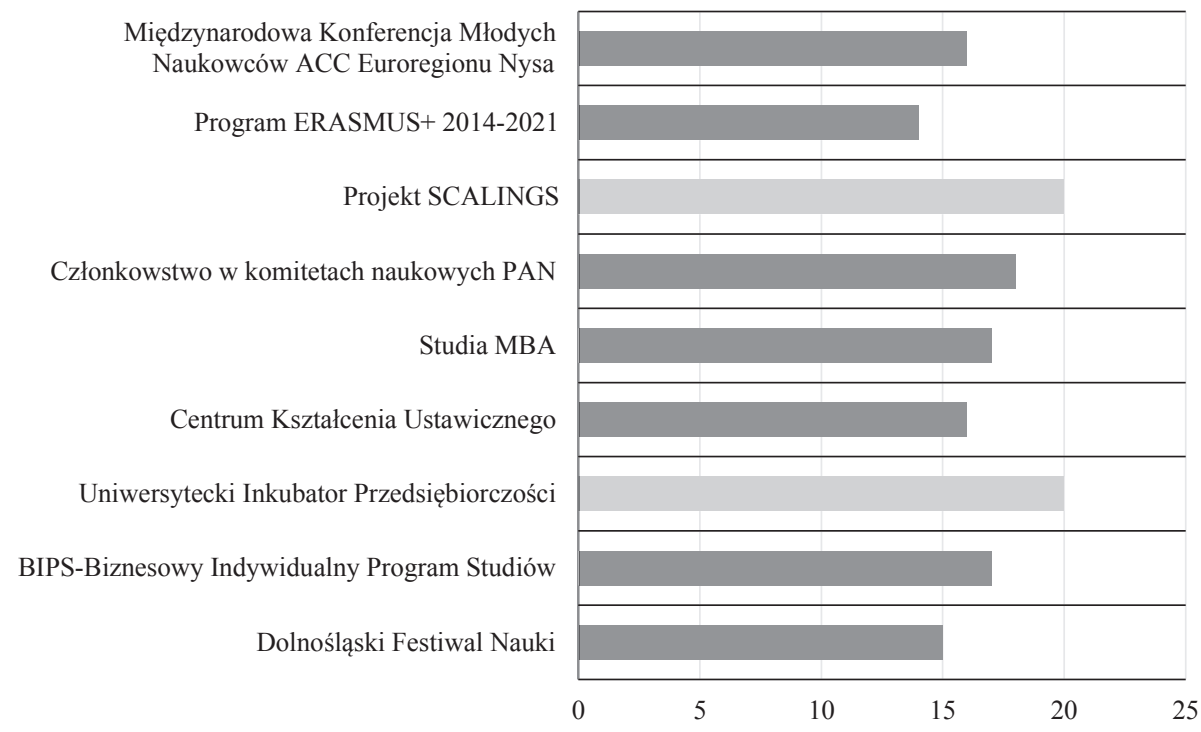

Rys. 2. Wartość zidentyfikowanych zasobów Uniwersytetu Ekonomicznego we Wrocławiu Źródło: opracowanie własne na podstawie przeprowadzonych badań empirycznych.

Aby uzasadnić słuszność wyboru takich, a nie innych zasobów, w tab. 3 zaprezentowano wyniki przeprowadzonej analizy dwóch najwyżej ocenionych zasobów. 
Tabela 3. Analiza VRIO zasobów Uniwersytetu Ekonomicznego we Wrocławiu kluczowych dla Project SCALINGS

\begin{tabular}{|l|c|l|}
\hline \multicolumn{1}{|c|}{ Kryterium } & Ocena & \multicolumn{1}{|c|}{ Uzasadnienie } \\
\hline Wartość & 5 & $\begin{array}{l}\text { Unikalny projekt badawczy w ramach programu Horyzonty 2020 to ogromna } \\
\text { wartość pod względem zarówno naukowym, jak i wizerunkowym. Dzięki } \\
\text { współpracy z innymi uczelniami z Europy oraz idei przewodniej, jaką jest } \\
\text { włączenie społeczności do współtworzenia nauki i innowacji, stanowi on } \\
\text { ogromną wartość również w odniesieniu do strategii realizowanej przez UE } \\
\text { w latach 2016-2020, zwłaszcza dla działalności uczelni w zakresie społecz- } \\
\text { nej odpowiedzialności biznesu. }\end{array}$ \\
\hline Rzadkość & 5 & $\begin{array}{l}\text { Rzadkość jest ważna ze względu na charakter konkursu, jaki był przeprowa- } \\
\text { dzany w celu przyłączenia się do projektu. Jest to innowacyjny projekt, do } \\
\text { którego dostęp uzyskało jeszcze tylko kilkanaście innych uczelni z Europy. }\end{array}$ \\
\hline Imitowalność & 5 & $\begin{array}{l}\text { Projekt jest unikalny, niemożliwy do imitacji ze względu na konkurs, jaki } \\
\text { wyłonił jego uczestników, oraz środki finansowe przyznane w ramach umo- } \\
\text { wy grantowej. }\end{array}$ \\
\hline Organizacja & 5 & $\begin{array}{l}\text { Koordynatorzy projektu to pracownicy uniwersytetu, z dużym doświadcze- } \\
\text { niem przy realizowaniu projektów badawczych. }\end{array}$ \\
\hline Razem & 20 & \\
\hline
\end{tabular}

Źródło: opracowanie własne na podstawie www.ue.wroc.pl.

Tabela 4. Analiza VRIO zasobów Uniwersytetu Ekonomicznego we Wrocławiu kluczowych dla Uniwersyteckiego Inkubatora Przedsiębiorczości

\begin{tabular}{|l|c|l|}
\hline \multicolumn{1}{|c|}{ Kryterium } & Ocena & \multicolumn{1}{c|}{ Uzasadnienie } \\
\hline Wartość & 5 & $\begin{array}{l}\text { Innowacyjny program, wzmacniający współpracę uczelni ze środo- } \\
\text { wiskiem biznesowym wśród absolwentów szkół wyższych, studen- } \\
\text { tów czy pracowników. Tworzy znaczną wartość dla uniwersytetu } \\
\text { pod względem jego wizerunku oraz realizacji zapisanej wizji. Dzię- } \\
\text { ki inicjatywie wzrasta przedsiębiorczość w regionie. }\end{array}$ \\
\hline Rzadkość & 5 & $\begin{array}{l}\text { Funkcjonuje w ramach Regionalnego Programu Operacyjnego Wo- } \\
\text { jewództwa Dolnośląskiego 2014-2020, co oznacza stricte określo- } \\
\text { ne ramy czasowe programu, przez co stopień jego rzadkości jest } \\
\text { wysoki. }\end{array}$ \\
\hline Imitowalność & 5 & $\begin{array}{l}\text { Ze względu na wysokie koszty i ograniczone środki, jakie były przy- } \\
\text { znawane w ramach Regionalnego Programu Operacyjnego, imitacja } \\
\text { jest właściwie niemożliwa. Wartość projektów realizowanych w ra- } \\
\text { mach Inkubatora Przedsiębiorczości wynosi ponad 10 mln zł. }\end{array}$ \\
\hline Organizacja & 5 & $\begin{array}{l}\text { Rada, która została powołana do organizacji, składa się z bardzo } \\
\text { doświadczonych osób, zajmujących stanowiska prezesów firm oraz } \\
\text { działających w różnego rodzaju organizacjach o krajowym czy też } \\
\text { szerszym zasięgu działalności. }\end{array}$ \\
\hline Razem & 20 & \\
\hline
\end{tabular}

Źródło: opracowanie własne na podstawie www.ue.wroc.pl. 


\subsection{Kluczowe zasoby wizerunkowe w odniesieniu do strony zewnętrznej organizacji}

Finalny etap analizy Uniwersytetu Ekonomicznego we Wrocławiu skupił się na stronie zewnętrznej uczelni. Do tego celu został wykorzystany ranking polskich uczelni ekonomicznych, który jest publikowany co roku przez gazetę „Rzeczpospolita”. W rankingu tym brane są pod uwagę cztery kategorie, którym przypisane są wagi procentowe. Wspomniane kategorie to: kariery absolwentów, jakość nauki, potencjał naukowy, a także umiędzynarodowienie. W 2018 roku Uniwersytet Ekonomiczny we Wrocławiu zajął piąte miejsce. Nie oznacza to jednak, że na podstawie przytoczonego poniżej rankingu uczelni ekonomicznych nie udało się zidentyfikować zasobów, które można wykorzystać przy budowaniu wizerunku.

Tabela 5. Ranking uczelni ekonomicznych w 2018 roku

\begin{tabular}{|c|c|c|c|c|c|c|}
\hline \multirow[b]{2}{*}{ Lp. } & \multirow[b]{2}{*}{ Nazwa uczelni } & \multirow{2}{*}{$\begin{array}{c}\text { Suma } \\
\text { punktów } \\
\text { w rankingu }\end{array}$} & \multicolumn{4}{|c|}{ Suma punktów według kategorii } \\
\hline & & & $\begin{array}{c}\text { kariery } \\
\text { absolwentów } \\
\text { waga }=25 \%\end{array}$ & $\begin{array}{c}\text { jakość } \\
\text { nauczania } \\
\text { waga }=25 \%\end{array}$ & $\begin{array}{c}\text { potencjał } \\
\text { naukowy } \\
\text { waga }=20 \%\end{array}$ & $\begin{array}{c}\text { umiędzy- } \\
\text { narodowienie } \\
\text { waga }=15 \%\end{array}$ \\
\hline 1 & $\begin{array}{l}\text { Szkoła Główna } \\
\text { Handlowa } \\
\text { w Warszawie }\end{array}$ & 86,67 & 36,67 & 21,92 & 15,17 & 12,92 \\
\hline 2 & $\begin{array}{l}\text { Akademia } \\
\text { Leona } \\
\text { Koźmińskiego } \\
\text { w Warszawie }\end{array}$ & 64,25 & 30 & 13,58 & 10,25 & 10,42 \\
\hline 3 & $\begin{array}{l}\text { Uniwersytet } \\
\text { Ekonomiczny } \\
\text { w Poznaniu }\end{array}$ & 54,42 & 16,67 & 18,33 & 11,92 & 7,5 \\
\hline 4 & $\begin{array}{l}\text { Uniwersytet } \\
\text { Ekonomiczny } \\
\text { w Katowicach }\end{array}$ & 47,58 & 23,33 & 9,83 & 6,92 & 7,5 \\
\hline 5 & $\begin{array}{l}\text { Uniwersytet } \\
\text { Ekonomiczny } \\
\text { we Wrocławiu }\end{array}$ & 47,5 & 13,33 & 14,5 & 15,5 & 4,17 \\
\hline 6 & $\begin{array}{l}\text { Uniwersytet } \\
\text { Ekonomiczny } \\
\text { w Krakowie }\end{array}$ & 40,67 & 16,67 & 9,33 & 9,67 & 5 \\
\hline
\end{tabular}

Źródło: www.rp.pl/Biznes/311079957-Najlepsze-uczelnie-ekonomiczne-w-Polsce-SGH-po-raztrzeci-kroluje-na-podium.html?fbclid=IwAR2t3XpYgV428aiJo-F67nUPECnLcFWkOEejQSBS-B7bxpASr7htIr4jMKo.

Patrząc na ranking z perspektywy miejsca zajmowanego przez Uniwersytet Ekonomiczny we Wrocławiu, trzeba zauważyć stosunkowo niską pozycję w całym 
rankingu. Prowadząc dywagacje na temat wizerunku, należy się jednak skupić na zasobach, które będą go umacniać. Ranking - jako perspektywa postrzegania uczelni z zewnątrz, a także ocena jej poszczególnych aspektów działalności - dostarczył informacji, które powinny zostać ujęte w kontekście budowania wizerunku, a co więcej - można je traktować jako spójne z wizją, misją i strategią organizacji. Autor ma tutaj na myśli 2 kategorie rankingu, w których wrocławski UE wypadł bardzo dobrze. Jest to jakość nauczania. Pod tym względem uniwersytet ustępuje wyłącznie Szkole Głównej Handlowej w Warszawie. Drugie kryterium to potencjał naukowy, czyli kategoria, w której uniwersytet zajmuje pierwsze miejsce. To właśnie te informacje powinny zostać uwzględnione w procesie budowania wizerunku.

\section{Podsumowanie}

Wizerunek organizacji stał się w ostatnich latach kluczowym zasobem w odniesieniu zarówno do tych o charakterze komercyjnym, jak i publicznym, takich jak uczelnie. $\mathrm{Na}$ taki stan rzeczy wpływ mają m.in. rosnąca konkurencja oraz uzyskanie przewagi przez zasoby niematerialne nad materialnymi w budowaniu strategii organizacji. Uniwersytet Ekonomiczny we Wrocławiu, który stanowił przedmiot badań pod kątem identyfikacji zasobów, jakie mogą zostać wykorzystane w procesie budowania wizerunku, okazuje się dysponować bardzo szerokim portfelem działań, projektów, inicjatyw itd. Należy traktować je w kategoriach umożliwiających tworzenie wizerunku uczelni w sposób spójny z misją, wizją i strategią uczelni.

Aspektem, na jaki powinno się zwrócić szczególną uwagę, jest odpowiednia identyfikacja i ocena posiadanych zasobów, co możliwe jest wyłącznie dzięki dogłębnej analizie wnętrza organizacji, przy jednoczesnym zwracaniu uwagi na szanse pojawiające się na zewnątrz, czego odzwierciedleniem jest przywołany ranking uczelni ekonomicznych. Zarzuty formułowane w stronę podejścia zasobowego, kierowane choćby przez Portera - wskazujące, że może ono być wyłącznie uzupełnieniem analizy branżowej, a same zasoby nie są cenne, jeśli nie są analizowane pod kątem rynkowym [Porter 1991] - w przypadku budowania wizerunku nie muszą być potwierdzone, pod warunkiem że występuje ich spójność z misją, wizją oraz strategią organizacji.

Stworzenie odpowiedniego wizerunku uczelni, dającego szansę na trwałą przewagę konkurencyjną, to działanie długofalowe, które nie może zostać zastąpione wyłącznie jednorazowymi działaniami promocyjnymi. Aby sam wizerunek stał się kluczowym dla organizacji zasobem, musi opierać się na takich działaniach, projektach czy inicjatywach, które będą odzwierciedlały jej wizję oraz misję. Bez zachowania tej autentyczności szanse powodzenia są znikome. Na takim podejściu musi zostać również oparta próba identyfikacji zasobów organizacji, tak jak miało to miejsce w przypadku analizy przeprowadzonej na potrzeby tego artykułu.

Przyszłość będzie stawiała kolejne wyzwania przed organizacjami poszukującymi zasobów dających im przewagę konkurencyjną. Wizerunek może stanowić zasób, który przez wiele lat będzie trwale wpływał na ich powodzenie. 


\section{Literatura}

Altkorn J., 2004, Wizerunek firmy, Wyższa Szkoła Biznesu, Dąbrowa Górnicza.

Collis D.J., Montgomery C.A., 2008, Competing on resources, Harvard Business Review, 86(7-8).

Dejnaka A., 2012, Identyfikacja wizualna uczelni a budowanie wizerunku marki, Zeszyty Wyższej Szkoły Bankowej w Poznaniu.

Dunaj B. (red.), 1996, Słownik współczesnego języka polskiego, Wilga, Warszawa.

Dyer J.H., Singh H., 1998, The relational view: cooperative strategy and sources of interorganizational competitive advantage, Academy of Management Review, 24, s. 660-679.

Hamel G., Prahald C.K., 1993, Strategy as stretch and leverage, Harvard Business Review, 71(2).

Iwankiewicz-Rak B., 2007, Wizerunek organizacji niedochodowych - znaczenie i kreowanie, Prace Naukowe Akademii Ekonomicznej we Wrocławiu, nr 1171, Marketing, s. 86-96.

Klimas P., 2014, Sieci innowacji. Implikacje bliskości organizacyjnej, Wydawnictwo Uniwersytetu Ekonomicznego, Katowice.

Kotas M., 2014, Wizerunek organizacji publicznej jako instrument efektywnego komunikowania z interesariuszami, Wydawnictwo Uniwersytetu Ekonomicznego, Katowice.

Krupski R., 2012, O okazjach raz jeszcze. Trochę teorii i raportu z badań, Przegląd organizacji, 11, s. 3-5.

Krzyżak M., 2014, Istota i potrzeba budowania wizerunku uczelni, Wyższa Szkoła Wojsk Lądowych im. Tadeusza Kościuszki we Wrocławiu.

Lichtarski J., 2014, Profile orientacji w zarządzaniu przedsiębiorstwem i ksztattujace je czynniki, [w:] H. Jagoda, J. Lichtarski, Kierunki i dylematy rozwoju nauki i praktyki zarądzania przedsiębiorstwem, Wyd. Uniwersytetu Ekonomicznego we Wrocławiu, Wrocław.

Marczewska M., 2016, Podejście zasobowe do organizacji, [w:] Klincewicz K. (red.), Zarzadzanie, organizacje i organizowanie - przeglad perspektyw teoretycznych, Wydawnictwo Naukowe Wydziału Zarządzania Uniwersytetu Warszawskiego, Warszawa.

Niemczyk J., 2013, Od planu do sieci, Wyd. Uniwersytetu Ekonomicznego we Wrocławiu, Wrocław.

Porter M., 1991, Towards a dynamic theory of strategy, Strategic Management Journal, vol. 12, s. 95-117.

Prahald C.K., Hamel G., 1990, The core competence of the corporation, Harvard Business Review.

Rozwadowska B., 2002, Public Relations - teoria, praktyka, perspektywy, Studio Emka, Warszawa.

Stańczyk-Hugiet E., 2011, W poszukiwaniu renty..., Przegląd Organizacji, 9, s. 6-8. 